\title{
INWESTYCJE W ZAKRESIE ODNAWIALNYCH ŹRÓDEL ENERGII W ŚWIETLE WYMAGAŃ ZRÓWNOWAŻONEGO ROZWOJU NA PRZYKŁADZIE WOJEWÓDZTWA LUBELSKIEGO
}

\author{
Karolina Gałązka \\ Politechnika Częstochowska \\ Wydział Zarządzania
}

\begin{abstract}
Streszczenie: Podstawowym warunkiem zapewnienia pozycji rynkowej przedsiębiorstwa jest nie tylko sprawność bieżącego zarządzania, ale także umiejętność podejmowania optymalnych decyzji inwestycyjnych i wskazania źródeł ich finansowania. Inwestycje w zakresie odnawialnych źródeł energii są szeroko finansowane przez banki i instytucje, które oferują preferencyjne kredyty na przedsięwzięcia związane z ochroną środowiska, czyli na instalacje związane $\mathrm{z}$ energią odnawialną. Zaledwie $11 \%$ (http://strateg. stat.gov.pl) w łącznym pozyskiwaniu energii pochodzi z odnawialnych źródeł, co może świadczyć o tym, że proces ten jest na początkowym etapie, jednak z ogromnym potencjałem na szybki rozwój. W artykule zaprezentowano źródła finansowania inwestycji małych i średnich przedsiębiorstw w zakresie odnawialnych źródeł energii. Analiza inwestycji sektora MŚP została przeprowadzona na podstawie informacji statystycznej oraz badań ankietowych w regionie województwa lubelskiego. W badaniu działań inwestycyjnych przedsiębiorstw na Lubelszczyźnie duże znaczenie przypisano inwestycjom w zakresie odnawialnych źródeł energii oraz kwestii nakładów inwestycyjnych.
\end{abstract}

Słowa kluczowe: inwestycje, odnawialne źródła energii, zrównoważony rozwój, źródła finansowania

DOI: 10.17512/znpcz.2016.2.04

\section{Wprowadzenie}

Inwestycje pełnią ważną rolę w procesie rozwoju i poprawie konkurencyjności sektora małych i średnich przedsiębiorstw w Polsce. Mniejsze jednostki gospodarcze powinny więc przyjąć odpowiednie kierunki i rozmiary inwestowania. Inwestycja w energetykę odnawialną jest dość złożonym i zaawansowanym przedsięwzięciem, zarówno $\mathrm{z}$ technicznego, logistycznego, ekonomicznego, a przede wszystkim z prawnego punktu widzenia. W zależności od rodzaju źródła, technologii oraz skali przedsięwzięcia, a także lokalizacji przyszłej inwestycji procedury administracyjno-prawne mogą się znacząco różnić od siebie. Każda inwestycja wymaga szeregu pozwoleń, decyzji i uzgodnień, a zmieniające się ciągle przepisy powodują konieczność wprowadzania zmian w harmonogramie realizacji podjętej inwestycji (Ćwil 2010, s. 1). 
Celem artykułu jest ocena dotychczasowych działań inwestycyjnych w zakresie odnawialnych źródeł energii małych i średnich przedsiębiorstw. Podmiotem badań są jednostki zlokalizowane na obszarze województwa lubelskiego. W pracy wykorzystano wyniki badań ankietowych przeprowadzonych w trzech edycjach w latach 2010-2015 na grupie łącznie 640 mikro, małych i średnich przedsiębiorstw funkcjonujących na obszarze województwa lubelskiego. Po raz pierwszy w trzeciej edycji badań zapytano o inwestycje w zakresie odnawialnych źródeł energii. W kolejnych edycjach nastąpi kontynuacja badań w podjętym temacie. $\mathrm{W}$ artykule poddano analizie charakter przedsięwzięć inwestycyjnych, ze szczególnym uwzględnieniem inwestycji w zakresie odnawialnych źródeł energii, wysokość nakładów i źródła ich finansowania. Niski poziom inwestycji jest jednym z kluczowych problemów gospodarki polskiej. Tymczasem wiedza i umiejętne jej wykorzystanie stały się w ostatnim czasie podstawowym czynnikiem decydującym o atrakcyjności i konkurencyjności gospodarki na rynku globalnym. Biorąc pod uwagę wymienione czynniki, przyjęto hipotezę badawczą o umiarkowanym poziomie działań inwestycyjnych w zakresie odnawialnych źródeł energii firm z sektora małych i średnich przedsiębiorstw w województwie lubelskim.

\section{Idea zrównoważonego rozwoju a inwestycje w odnawialne źródła energii}

Współcześnie podejmuje się coraz częściej działania mające na celu ograniczenie globalnego niszczenia środowiska, a tym samym uwidoczniona zostaje potrzeba wykorzystania naturalnych źródeł energii. Świadomość dotycząca istnienia alternatywnych do konwencjonalnych źródeł energii nadal dociera do społeczeństwa bardzo powoli. Konieczność stosowania wymogów ekologicznych doprowadza do coraz większych zmian w podejściu do problemu racjonalnego korzystania $\mathrm{z}$ zasobów naturalnych, a tym samym do racjonalnego zarządzania energią (SuskaSzczerbicka 2011, s. 5-6). Konsekwencje bieżących trendów doprowadziły do zainteresowania się opinii publicznej i do pobudzenia społecznej odpowiedzialności za stan środowiska. W większości obiektów występuje możliwość oszczędzania energii, które ma wymiar ekonomiczny, społeczny i ekologiczny. Z tego względu istnieje konieczność kształtowania w społeczeństwie świadomości znaczenia zarządzania energią elektryczną.

Energetyka jest specyficznym obszarem gospodarki, ze względu na zakres jej oddziaływania społecznego, ekologicznego i ekonomicznego oraz duże, jeszcze niezagospodarowane możliwości. Trudno współcześnie znaleźć dziedzinę, w której nie odwoływano by się do koncepcji zrównoważonego rozwoju. W energetyce zatem również można odnaleźć takie powiązania (Mazur-Wierzbicka 2011, s. 244). Sformułowano wiele określeń terminu „sustainability”. Termin zrównoważonego rozwoju wywodzi się z łacińskiego słowa sustenare (podtrzymywać), co oznacza, że coś może trwać na zawsze (http://imik.wip.pw.edu.pl/innowacje25/strona12.htm). Jest on obecny zarówno w dokumentach międzynarodowych, jak i krajowych, strategiach, polityce czy programach unijnych. Wartościowego przeglądu omawianej koncepcji dokonał G. Haugen (Haugen 2014). Z opracowania tego autora wynika, 
że koncepcja sustainability preferuje uwzględnianie w działalności przedsiębiorstw i innego rodzaju organizacji nie tylko celów ekonomicznych, lecz również społecznych i ekologicznych - w ten sposób mogą się one przyczyniać do równoważenia potrzeb międzypokoleniowych (Pabian 2015, s. 8).

Narodziny koncepcji zrównoważonego rozwoju spowodowały zwrócenie uwagi na odpowiednie korzystanie z zasobów naturalnych, w szczególności tych, których nie da się odtworzyć. Podkreślano to szczególnie w odniesieniu do zasobów, których przeznaczenie gwarantowało otrzymywanie energii (Piechota 2014, s. 56).

Rozwój ludzkości, a co za tym idzie - rosnący popyt na energię, oraz w dalszym ciągu obecność na mapie świata miejsc, gdzie energia elektryczna nie dociera (tzw. białe plamy), stały się przyczyną rozwinięcia problematyki energetyki w odniesieniu do zrównoważonego rozwoju. Termin „zrównoważony rozwój energetyczny" (sustainable energy) należy rozumieć jako taki sposób gospodarowania energią, który po pierwsze - zapewni dostęp do wystarczającej ilości energii nie tylko nam, lecz także przyszłym pokoleniom, a po drugie - nie będzie oddziaływał negatywnie na środowisko naturalne w skali lokalnej, a przede wszystkim globalnej (Piechota 2014, s. 57).

Podsumowując doczasowe rozważania, warto zacytować jeszcze K. Dubel, która twierdzi, że zrównoważony rozwój to rozwój gospodarczy pożądany społecznie, uzasadniony ekonomicznie i dopuszczalny ekologicznie (Dubel 1998, s. 25-26). Zrównoważony rozwój jest procesem długotrwałym. Założenie istnienia rozwiązania kompromisowego, łączącego ekonomiczny rozwój oraz zachowanie środowiska w zadowalającym stanie, uznać należy za fundament koncepcji zrównoważonego rozwoju (Krawczyk-Sokołowska (red.) 2012, s. 25-28).

H. Rechul wskazuje że warto inwestować w zrównoważony rozwój energetyczny (Rechul 2004, s. 1). Dla zaktywizowania zrównoważonego rozwoju energetyki konieczne jest podjęcie działań inwestycyjnych w kierunku zwiększenia udziału odnawialnych źródeł energii w globalnym bilansie energetycznym oraz zwiększenia efektywności wykorzystania energii (Rechul 2003). Działania te powinny przynajmniej częściowo rozwiązać najdotkliwsze problemy energetyczne, związane ze zmianami klimatu ziemskiego czy z wyczerpywaniem się paliw kopalnych jako tradycyjnych surowców energetycznych (Rechul 2004, s. 1).

\section{Inwestycje w odnawialne źródła energii w świetle dotychczasowych badań}

Wzrost znaczenia odnawialnych źródeł energii związany jest z licznymi zachętami do podejmowania inwestycji $w$ instalacje energetyczne. Liczne dotacje i subwencje, a także preferencyjne kredyty sprzyjają zwiększaniu liczby inwestycji w OZE. Dla inwestorów dostępne są liczne programy wpierające, jak choćby w krajach UE w ramach kolejnych perspektyw finansowych. Inwestycje w OZE sprzyjają efektywności wykorzystania zasobów (Piechota 2014, s. 60).

Inwestycje związane z optymalizacją zużycia energii mogą przynieść pozytywne skutki na poziomie kraju, powodując wzrost konkurencyjności jego gospodarki na rynku światowym, ale również mogą być korzystne na szczeblu pojedynczej 
organizacji, gwarantując jej obniżenie kosztów energii i poprawę wizerunku firmy. Jednakże, mimo zwiększającej się świadomości ekologicznej, odsetek firm podejmujących tego typu działania jest nadal niski (Kucęba, Koszarek-Cyra 2015, s. 376).

Jak wskazuje raport opracowany przez Bloomberg New Energy Finance, w latach 2004-2012 zainwestowano ponad 1500 mld USD na rzecz zrównoważonego rozwoju energetycznego (Bloomberg New Energy Finance 2013). Intensywny wzrost inwestycji w sektorze energetyki przypadł na lata 2004--2007. Związane było to z egzekwowaniem postanowień Konferencji Organizacji Narodów Zjednoczonych w Johannesburgu. Wysokie tempo wzrostu tych inwestycji utrzymywało się do roku 2008, aby w roku 2009 przyjąć wartość ujemną, co było skutkiem światowego kryzysu na rynkach finansowych. Kolejne lata przyniosły znaczny wzrost wartości inwestycji w energetykę zrównoważoną, aby w roku 2011 osiągnąć wielkość 302 mld USD (Piechota 2014, s. 58).

Kształtując koncepcję zrównoważonego rozwoju, w szczególności w odniesieniu do energetyki, zwracano uwagę na wykorzystanie odnawialnych źródeł energii. W latach 2004-2012 wartość inwestycji w odnawialne źródła energii na świecie wyniosła 1362 mld USD. W samym 2012 roku zainwestowano 244 mld USD, głównie w krajach rozwiniętych. Rok 2012 był pierwszym, w którym wartość inwestycji w tym sektorze była niższa niż w roku poprzednim, i to o $35 \mathrm{mld}$ USD. Inwestycje w odnawialne źródła energii w 2012 roku charakteryzują się dużą rozpiętością zarówno w zasoby, w które inwestowano, jak i skalą tych inwestycji w krajach rozwiniętych i rozwijających się. Ogólnie inwestowano głównie $\mathrm{w}$ energię słoneczną oraz wiatrową. Kraje rozwijające się więcej zainwestowały natomiast w biomasę, energetykę wodną oraz geotermalną (Piechota 2014, s. 60).

Badania ankietowe są bardzo popularną formą zbierania informacji o krajowych inwestycjach w zakresie odnawialnych źródeł energii. W literaturze można znaleźć wiele sprawozdań i analiz przeprowadzonych na podstawie badań ankietowych. Niestety większość z nich opiera się na analizie kilkunastu lub kilkudziesięciu podmiotów, często funkcjonujących na obszarze wybranego województwa lub regionu. Badania kompleksowe, przeprowadzone na większej liczbie podmiotów, są rzadkością. Przeprowadzane są one najczęściej w ramach szerszego badania MŚP, np. opracowania PARP. W Tabeli 1 przedstawiono wybrane badania dotyczące inwestycji w zakresie OZE w Polsce. 
Tabela 1. Zestawienie informacji o wybranych badaniach w obszarze dzialań inwestycyjnych w OZE

\begin{tabular}{|c|c|c|c|c|}
\hline Lp. & Rok & Temat badań & Cel badania & Główne wnioski \\
\hline 1. & $\begin{array}{c}2007- \\
2013\end{array}$ & $\begin{array}{l}\text { Źródła finanso- } \\
\text { wania inwestycji } \\
\text { w zakresie } \\
\text { odnawialnych } \\
\text { źródeł energii }\end{array}$ & $\begin{array}{l}\text { Przedstawienie } \\
\text { i porównanie sposobów } \\
\text { finansowania inwestycji } \\
\text { w zakresie odnawial- } \\
\text { nych źródeł }\end{array}$ & $\begin{array}{l}\text { Dotacje i fundusze na rozwój ekoinnowacji - istnieje } \\
\text { szeroki wachlarz instrumentów wspierających inwestycje } \\
\text { w zakresie odnawialnych źródeł energii, jednak nie każdy } \\
\text { przedsiębiorca jest tego świadomy } \\
\text { (http://www.rsiwielkopolska.p1/files/59/32457e2a-9f44- } \\
\text { 453f-8443-801ad9db7c9e.pdf). }\end{array}$ \\
\hline 2. & 2013 & $\begin{array}{l}\text { Determinanty } \\
\text { wykorzystania } \\
\text { odnawialnych } \\
\text { źródeł energii } \\
\text { w Polsce }\end{array}$ & $\begin{array}{l}\text { Wskazanie uwarunko- } \\
\text { wań rozwoju inwestycji } \\
\text { w OZE w Polsce }\end{array}$ & $\begin{array}{l}\text { Sektor OZE od momentu wstąpienia Polski do UE zaczął } \\
\text { się rozwijać. Jednak podczas wielu procesów inwestycyj- } \\
\text { nych napotykane są trudności administracyjne, prawne } \\
\text { oraz coraz częściej społeczne. Brak jednolitych norm } \\
\text { prawnych i przepisów administracyjnych hamuje rozwój } \\
\text { inwestycji w OZE w Polsce (Zabłocki 2013, s. 29-44). }\end{array}$ \\
\hline 3. & 2014 & $\begin{array}{l}\text { Koszty energii } \\
\text { elektrycznej } \\
\text { z odnawialnych } \\
\text { źródeł energii }\end{array}$ & $\begin{array}{l}\text { Przedyskutowano } \\
\text { systemy wspomagające } \\
\text { rozwój OZE. Przedsta- } \\
\text { wiono własne oblicze- } \\
\text { nia efektywności } \\
\text { ekonomicznej wybranej } \\
\text { technologii } \\
\text { OZE }\end{array}$ & $\begin{array}{l}\text { Każda inwestycja w sferze wytwarzania musi być poprze- } \\
\text { dzona skrupulatnym studium wykonalności. Zaprezento- } \\
\text { wane w artykule wyniki obliczeń dla konkretnego przy- } \\
\text { padku to tylko fragment analizy. Decydujące znaczenie } \\
\text { będzie odgrywać zapewnienie finansowania inwestycji, } \\
\text { szczególnie w sytuacji dużego ryzyka biznesowego pono- } \\
\text { szonego przez inwestora oraz funkcjonujący system } \\
\text { wsparcia OZE (Sowiński 2014, } \\
\text { s. 127-131). }\end{array}$ \\
\hline 4. & 2014 & $\begin{array}{l}\text { Inwestycje } \\
\text { w odnawialne } \\
\text { źródła energii } \\
\text { a polityka } \\
\text { zrównowa- } \\
\text { żonego rozwoju }\end{array}$ & $\begin{array}{l}\text { Przybliżenie tematyki } \\
\text { inwestowania } \\
\text { w odnawialne } \\
\text { źródła energii (OZE) } \\
\text { w odniesieniu do } \\
\text { warunków zrównowa- } \\
\text { żonego } \\
\text { rozwoju } \\
\end{array}$ & $\begin{array}{l}\text { Ostatnie lata przyniosły znaczny wzrost liczby inwestycji } \\
\text { w odnawialne źródła energii. Konieczność sprostania } \\
\text { wymogom Unii Europejskiej w dziedzinie poszanowania } \\
\text { energii, a tym samym dążenie do pełni koncepcji zrówno- } \\
\text { ważonego rozwoju, wiązać się będzie z jeszcze bardziej } \\
\text { dynamicznym wzrostem udziału energii pochodzącej z } \\
\text { OZE w zużyciu energii ogółem (Piechota 2014, s. 54-65). }\end{array}$ \\
\hline 5. & 2015 & $\begin{array}{l}\text { Kierunki, barie- } \\
\text { ry, determinanty } \\
\text { zarządzania } \\
\text { energią w orga- } \\
\text { nizacjach MŚP }\end{array}$ & $\begin{array}{l}\text { Identyfikacja działań } \\
\text { związanych z redukcją } \\
\text { energochłonności } \\
\text { i źródeł finansowania } \\
\text { inwestycji związanych } \\
\text { z działalnością proeko- } \\
\text { logiczną w sektorze } \\
\text { MŚP }\end{array}$ & $\begin{array}{l}\text { Mimo stworzonych systemów wsparcia, a także ciągłego } \\
\text { wzrostu ekologicznej świadomości społecznej, liczba } \\
\text { inwestycji związanych z ograniczeniem energochłonności } \\
\text { w sektorze MŚP jest niewielka, zarówno } \\
\text { w Polsce, jak i w całej Unii Europejskiej. Wynika to } \\
\text { głównie z braku środków własnych, które przedsiębiorstwa } \\
\text { mogłyby przeznaczyć na ten cel, jak również } \\
\text { z niskiej świadomości co do zewnętrznych źródeł finanso- } \\
\text { wania i ewentualnych dodatkowych korzyści, które można } \\
\text { uzyskać, przeprowadzając działania optymalizacyjne } \\
\text { (Kucęba, Koszarek-Cyra 2015, s. 376-381). }\end{array}$ \\
\hline 6. & 2015 & $\begin{array}{l}\text { Analiza opłacal- } \\
\text { ności inwestycji } \\
\text { w produkcję } \\
\text { energii ze źródeł } \\
\text { odnawialnych }\end{array}$ & $\begin{array}{l}\text { Przeprowadzenie } \\
\text { opłacalności inwestycji } \\
\text { na przykładzie farmy } \\
\text { wiatrowej } \\
\text { przy założeniu wsparcia } \\
\text { rządu dla ,zielonej } \\
\text { energii” }\end{array}$ & $\begin{array}{l}\text { Ukazanie opłacalności inwestycji w farmę wiatrową, } \\
\text { pracującą na terenie Polski, przy założeniu, że produkcja } \\
\text { energii elektrycznej będzie odbywać się wraz z uzyskiwa- } \\
\text { niem wsparcia rządu dla producentów ,zielonej energii”. } \\
\text { Zaprezentowane dane oraz ich analiza potwierdzają opła- } \\
\text { calność inwestycji w farmę wiatrową o mocy } 30 \text { MW, a } \\
\text { czas zwrotu szacuje się na 8-9 lat (Gnatowska, Wąs 2015, } \\
\text { s. 23-33). }\end{array}$ \\
\hline
\end{tabular}

Źródło: Opracowanie własne

Biorąc pod uwagę problemy, jakie dotyczą inwestycji w OZE, na pierwszym miejscu plasuje się problem sposobu finansowania inwestycji. Wiele badań dotyka również opłacalności inwestycji w produkcję energii ze źródeł odnawialnych. Można znaleźć też szczegółowe opisy i analizy pojedynczych przypadków. 


\section{Charakterystyka próby badawczej}

W celu zweryfikowania hipotezy badawczej przeprowadzona została trzecia edycja badań. Respondentami byli właściciele i kadra menedżerska małych i średnich przedsiębiorstw w województwie lubelskim. Łącznie we wszystkich edycjach prowadzonych badań przekazano 640 kwestionariuszy ankiet dla małych i średnich przedsiębiorców.

W latach 2010-2011 przeprowadzono pierwsze badanie mające na celu m.in. zidentyfikowanie źródeł finansowania inwestycji małych i średnich przedsiębiorstw na wyznaczonym obszarze (Tabela 2). Badaniem objęto wówczas 240 jednostek gospodarczych, a w jego następstwie ustalono, iż przeanalizowane podmioty mają różne źródła finansowania oraz stopień ponoszonych wydatków w zależności od charakteru poczynionych działań inwestycyjnych. Celem potwierdzenia powyższych ustaleń w okresie 2012-2013 przeprowadzono ponowne badanie ankietowe. Badaniami objęto 254 losowo wybranych przedsiębiorców województwa lubelskiego, a do gromadzenia danych wykorzystano system komputerowy (arkusz kalkulacyjny). Obok metody ankietowej w analizie wykorzystano także metody statystyczne.

Tabela 2. Zestawienie prowadzonych badań ankietowych

\begin{tabular}{|c|c|c|c|c|}
\hline \multirow{2}{*}{ Lp. } & Wyszczególnienie & I edycja & II edycja & III edycja \\
\cline { 3 - 5 } & & $2010-2011$ & $2012-2013$ & $2014-2015$ \\
\hline \multirow{2}{*}{1.} & $\begin{array}{c}\text { Jednostki gospodarcze objęte } \\
\text { badaniem, w tym: }\end{array}$ & 240 szt. & 254 szt. & 147 szt. \\
\cline { 3 - 5 } & Ponoszące wydatki inwestycyjne & $52,08 \%$ & $52,76 \%$ & $70,75 \%$ \\
\hline 2. & Wprowadzające innowacje & $28,75 \%$ & $27,95 \%$ & $25,17 \%$ \\
\hline 4. & Współpracujące z jednostkami B+R & $7,50 \%$ & $11,02 \%$ & $8,84 \%$ \\
\hline 5. & Firmy rodzinne & $35,00 \%$ & $31,10 \%$ & $45,58 \%$ \\
\hline 6. & Wyrażające opinie wobec rozwoju & - & - & $100,00 \%$ \\
\hline
\end{tabular}

Źródło: Opracowanie własne na podstawie badań ankietowych przeprowadzonych w MŚP województwa lubelskiego w latach 2010-2015

Trzecia edycja badań przeprowadzona została w latach 2014-2015 i miała na celu zidentyfikowanie głównych problemów zarządzania $\mathrm{w}$ przedsiębiorstwach z sektora MŚP, a w szczególności poznanie opinii przedsiębiorców dotyczących inwestycji w odnawialne źródła energii. Badaniem objęto 147 jednostek gospodarczych.

Zdecydowana większość badanych przedsiębiorstw to mikroprzedsiębiorstwa, działające jako osoby fizyczne prowadzące działalność gospodarczą. Jest to ulubiona forma prowadzenia działalności, ponieważ pod wieloma względami jest ona najprostsza. W I edycji w przeprowadzonych badaniach udział wzięło 151 jednostek prowadzących działalność gospodarczą (63\% ogółu badanych firm), w II edycji 166 (65\% ogółu badanych firm rodzinnych), a w III edycji pośród 147 jednostek - 99 podmiotów prowadziło działalność gospodarczą, co stanowiło już nieco ponad $73 \%$ ogółu badanych podmiotów. Pozostałą część stanowiły spółki (średnio ponad 27\%) oraz działalności spółdzielcze (średnio prawie 3\%) i przedsiębiorstwa państwowe (średnio 4\%) (Tabela 3). 
Tabela 3. Forma organizacyjno-prawna ankietowanych przedsiębiorstw

\begin{tabular}{|c|c|c|c|c|}
\hline \multirow{2}{*}{ Lp. } & Wyszczególnienie & I edycja & II edycja & III edycja \\
\cline { 3 - 5 } & $2010-2011$ & $2012-2013$ & $2014-2015$ \\
\hline & $\begin{array}{c}\text { Jednostki gospodarcze objęte } \\
\text { badaniem, w tym: }\end{array}$ & $100,00 \%$ & $100,00 \%$ & $100,00 \%$ \\
\hline 2. & Działalność gospodarcza & $62,92 \%$ & $65,35 \%$ & $73,47 \%$ \\
\hline 3. & Działalność spółdzielcza & $3,33 \%$ & $2,76 \%$ & $2,04 \%$ \\
\hline 4. & Przedsiębiorstwo państwowe & $3,75 \%$ & $4,72 \%$ & $0,00 \%$ \\
\hline 5. & Spółka & $30,00 \%$ & $27,17 \%$ & $24,49 \%$ \\
\hline 6. & Spółka z o.o. & $13,75 \%$ & $12,60 \%$ & $10,20 \%$ \\
\hline 7. & Spółka cywilna & $8,33 \%$ & $5,12 \%$ & $7,48 \%$ \\
\hline 8. & Spółka akcyjna & $2,08 \%$ & $2,76 \%$ & $2,72 \%$ \\
\hline 9. & Spółka jawna & $5,83 \%$ & $5,12 \%$ & $4,08 \%$ \\
\hline 10. & Spółka partnerska & $0,00 \%$ & $1,57 \%$ & $0,00 \%$ \\
\hline
\end{tabular}

Źródło: Opracowanie własne na podstawie badań ankietowych przeprowadzonych w MŚP województwa lubelskiego w latach 2010-2015

Większość ankietowanych przedsiębiorstw funkcjonuje na rynku od 10 do 20 lat - średnio ponad $28 \%$ respondentów. Podobny odsetek, gdyż prawie $23 \%$, to podmioty, które swoją działalność prowadzą od 1 do 5 lat. Najmniej liczną grupę stanowiły jednostki, które dopiero rozpoczęły swoją działalność i funkcjonują krócej niż jeden rok (Tabela 4).

Tabela 4. Okres funkcjonowania ankietowanych przedsiębiorstw na rynku

\begin{tabular}{|c|c|c|c|c|}
\hline \multirow{2}{*}{ Lp. } & \multirow{2}{*}{ Wyszczególnienie } & I edycja & II edycja & III edycja \\
\hline & & $2010-2011$ & $2012-2013$ & $2014-2015$ \\
\hline 1. & $\begin{array}{l}\text { Jednostki gospodarcze objęte } \\
\text { badaniem, w tym: }\end{array}$ & $100,00 \%$ & $100,00 \%$ & $100,00 \%$ \\
\hline 2. & Krócej niż rok & $10,00 \%$ & $11,42 \%$ & $5,44 \%$ \\
\hline 3. & $1-5$ lat & $22,50 \%$ & $22,44 \%$ & $23,81 \%$ \\
\hline 4. & 5-10 lat & $20,00 \%$ & $20,47 \%$ & $21,09 \%$ \\
\hline 5. & 10-20 lat & $27,08 \%$ & $26,38 \%$ & $30,61 \%$ \\
\hline 6. & Powyżej 20 lat & $20,42 \%$ & $19,29 \%$ & $19,05 \%$ \\
\hline
\end{tabular}

Źródło: Opracowanie własne na podstawie badań ankietowych przeprowadzonych w MŚP województwa lubelskiego w latach 2010-2015

Tabela 5. Zasięg działalności ankietowanych przedsiębiorstw

\begin{tabular}{|c|c|c|c|c|}
\hline \multirow{2}{*}{ Lp. } & Wyszczególnienie & I edycja & II edycja & III edycja \\
\cline { 3 - 5 } & $2010-2011$ & $2012-2013$ & $2014-2015$ \\
\hline 1. & $\begin{array}{c}\text { Jednostki gospodarcze objęte } \\
\text { badaniem, w tym: }\end{array}$ & $100,00 \%$ & $100,00 \%$ & $100,00 \%$ \\
\hline 2. & Lokalny & $56,25 \%$ & $47,64 \%$ & $36,73 \%$ \\
\hline 3. & Regionalny & $20,42 \%$ & $18,50 \%$ & $27,21 \%$ \\
\hline 4. & Krajowy & $9,17 \%$ & $22,83 \%$ & $24,49 \%$ \\
\hline 5. & Międzynarodowy & $14,17 \%$ & $11,02 \%$ & $11,56 \%$ \\
\hline
\end{tabular}

Źródło: Opracowanie własne na podstawie badań ankietowych przeprowadzonych w MŚP województwa lubelskiego w latach 2010-2015 
Biorąc pod uwagę zasięg działalności ankietowanych przedsiębiorstw, zdecydowana większość podmiotów działa na rynku lokalnym - średnio $48 \%$, zaś o połowę mniej, gdyż zaledwie $22 \%$, na rynku regionalnym (Tabela 5).

Największą popularność $\mathrm{w}$ grupie przebadanych jednostek we wszystkich trzech edycjach zdobyły przedsiębiorstwa działające w branży usługowej. Na drugim miejscu uplasowały się jednostki handlowe (średnia ze wszystkich edycji prawie $31 \%$ ), a na trzecim - połączenie tych dwóch najpopularniejszych, czyli działalność handlowo-usługowa (branża mieszana - średnio ponad 25\%).

\section{Ocena działań inwestycyjnych w zakresie odnawialnych źródel energii w województwie lubelskim}

Trzecia edycja badań ankietowych została przeprowadzona na przełomie lat 2014-2015 pośród 147 przedsiębiorców województwa lubelskiego. Ankieta obejmowała 6 obszarów. Przedsiębiorcy i menedżerowie odpowiadali na pytania dotyczące bieżącej działalności firmy, źródeł finansowania inwestycji, a także oceniali własne postawy w kontekście podejmowania działań innowacyjnych oraz współpracy z jednostkami badawczo-rozwojowymi. Ponadto ze względu na wszechobecność stosowania wymogów ekologicznych, które doprowadzają do coraz większych zmian $\mathrm{w}$ podejściu do problemu racjonalnego korzystania $\mathrm{z}$ zasobów naturalnych, a tym samym do racjonalnego zarządzania energią, po raz pierwszy w III edycji badań, zapytano o inwestycje w zakresie odnawialnych źródeł energii. W kolejnych edycjach nastąpi kontynuacja badań w podjętym temacie, co umożliwi dokonanie analiz przedsięwzięć inwestycyjnych związanych z ochroną środowiska oraz dokonanie oceny, czy społeczeństwo widzi przyszłość w OZE, jako jednym ze sposobów na pozyskiwanie „zrównoważonej energii”?

$\mathrm{W}$ toku analizy planów inwestycyjnych badanej grupy przedsiębiorstw okazało się, że prawie $65 \%$ ankietowanych chciałoby zainwestować w odnawialne źródło energii. Jednak pośród nich zaledwie $22 \%$ podmiotów gotowych jest podjać takie wyzwanie jak najszybciej (Tabela 6 ). Natomiast w $43 \%$ przedsiębiorcy wykazują swoją gotowość do podjęcia tego rodzaju działań inwestycyjnych, jednak odkładają je na później.

Tabela 6. Czy gdyby mieli Państwo taką możliwość, to chcieliby Państwo zainwestować w małe odnawialne źródło energii?

\begin{tabular}{|c|l|c|}
\hline Lp. & \multicolumn{1}{|c|}{ Wyszczególnienie } & Udział odpowiedzi \\
\hline 1. & Tak, jak najszybciej & $21,77 \%$ \\
\hline 2. & Tak, ale później & $42,86 \%$ \\
\hline 3. & Nie chciałbym & $6,12 \%$ \\
\hline 4. & Trudno powiedzieć & $29,25 \%$ \\
\hline
\end{tabular}

Źródło: Opracowanie własne na podstawie badań ankietowych przeprowadzonych w MŚP województwa lubelskiego w latach 2014-2015

Pośród jednostek, które wyraziły swoją gotowość dotyczącą inwestycji w odnawialne źródło energii, ponad 25\% jednostek posiada już sprecyzowane plany na 
najbliższy rok działalności (Tabela 7). Natomiast $12 \%$ analizowanych przedsiębiorstw ma plany, ale $\mathrm{w}$ perspektywie najbliższych dwóch lat, a u prawie $9 \%$ przedsiębiorstw są to plany nawet ponad dwuletnie.

Tabela 7. Czy firma posiada już długookresowe plany działania związane z inwestycją w OZE?

\begin{tabular}{|c|l|c|}
\hline Lp. & \multicolumn{1}{|c|}{ Wyszczególnienie } & Udział odpowiedzi \\
\hline 1. & Posiadamy plany na najbliższy rok działalności & $25,17 \%$ \\
\hline 2. & Posiadamy plan działania na najbliższe dwa lata & $11,56 \%$ \\
\hline 3. & Posiadamy ponad dwuletnie plany działalności & $8,84 \%$ \\
\hline 4. & Nie planujemy długookresowo & $54,42 \%$ \\
\hline
\end{tabular}

Źródło: Opracowanie własne na podstawie badań ankietowych przeprowadzonych w MŚP województwa lubelskiego w latach 2014-2015

Analiza czynników skłaniających przedsiębiorców do zaniechania planów inwestycyjnych w zakresie odnawialnych źródeł energii ukazuje, że prawie $29 \%$ ankietowanych wskazało brak lub niewystarczającą ilość środków finansowych (Tabela 8). W tym miejscu należy zaznaczyć, iż inwestycje w zakresie odnawialnych źródeł energii są szeroko finansowane przez banki i instytucje, które oferują preferencyjne kredyty na przedsięwzięcia związane $\mathrm{z}$ ochroną środowiska, a w tym w szczególności na instalacje związane $\mathrm{z}$ energią odnawialną. W dalszej kolejności czynnikiem, który wpływa na brak planów inwestycyjnych w zakresie odnawialnych źródeł energii, jest brak potrzebnej wiedzy oraz wykwalifikowanej kadry. Największe trudności towarzyszą firmom na początku prowadzenia działalności. Związane są one właśnie $\mathrm{z}$ brakiem specjalistycznej wiedzy, szczególnie z zakresu zarządzania w warunkach konkurencji, z emitowaniem wartości bez korzyści ekonomicznych czy z długotrwałym procesem budowania wizerunku. Znaczna część przedsiębiorców wie, że edukacja $\mathrm{w}$ zakresie ochrony środowiska jest elementem niezbędnym $\mathrm{w}$ zmieniających się warunkach, ale nie wszyscy podążają za zmianami.

Tabela 8. Jakie są powody braku planów inwestycyjnych w zakresie OZE?

\begin{tabular}{|c|l|c|}
\hline Lp. & \multicolumn{1}{|c|}{ Wyszczególnienie } & Udział odpowiedzi \\
\hline 1. & Brak czasu na planowanie & $12,50 \%$ \\
\hline 2. & Brak lub niewystarczająca ilość środków finansowych & $28,75 \%$ \\
\hline 3. & Brak wykwalifikowanej kadry & $15,00 \%$ \\
\hline 4. & Brak potrzebnej wiedzy & $17,50 \%$ \\
\hline 5. & $\begin{array}{l}\text { Planowanie nie jest konieczne w tej wielkości przedsiębior- } \\
\text { stwie }\end{array}$ & $26,25 \%$ \\
\hline
\end{tabular}

Źródło: Opracowanie własne na podstawie badań ankietowych przeprowadzonych w MŚP województwa lubelskiego w latach 2014-2015

Poddając analizie średni czas oczekiwania na zwrot poniesionych kosztów z tytułu inwestycji w odnawialne źródła energii, przekonać się można, iż zaledwie $21 \%$ podmiotów oczekuje, że średni okres zwrotu ukształtuje się na poziomie nie dłuższym niż 2 lata (Tabela 9). Natomiast pośród ogółu przedsiębiorców wyrażających swoją gotowość do podjęcia tego rodzaju działań inwestycyjnych, jednak 
odkładających je na później, w 23\% trudno jest im określić szacunkowy czas oczekiwania na zwrot poniesionych nakładów.

Tabela 9. Średni czas oczekiwania na zwrot poniesionych kosztów z tytułu inwestycji w odnawialne źródła energii

\begin{tabular}{|c|c|c|}
\hline Lp. & Wyszczególnienie & Udział odpowiedzi \\
\hline 1. & Trudno powiedzieć & $22,45 \%$ \\
\hline 2. & Więcej niż 10 lat & $6,80 \%$ \\
\hline 3. & $9-10$ lat & $8,16 \%$ \\
\hline 4. & $7-8$ lat & $7,48 \%$ \\
\hline 5. & 5-6 lat & $15,65 \%$ \\
\hline 6. & 3-4 lata & $19,05 \%$ \\
\hline 7. & Nie dłużej niż 2 lata & $20,41 \%$ \\
\hline
\end{tabular}

Źródło: Opracowanie własne na podstawie badań ankietowych przeprowadzonych w MŚP województwa lubelskiego w latach 2014-2015

Najchętniej wybieranym źródłem energii, z którego gotowi byliby skorzystać przedsiębiorcy, są kolektory słoneczne zapewniające oszczędność na rachunkach za ciepło (ponad 29\%), a w dalszej kolejności panele fotowoltaiczne zapewniające oszczędność na rachunkach za energię elektryczną (ponad 28\%) (Tabela 10). Najmniej popularnym źródłem odnawialnej energii pośród przedsiębiorców województwa lubelskiego okazały się być kotły na biomasę czy mikrobiogazownie.

Tabela 10. Zestawienie odnawialnych źródel energii, w które najchętniej zainwestowaliby przedsiębiorcy

\begin{tabular}{|c|c|c|}
\hline Lp. & Wyszczególnienie & $\begin{array}{c}\text { Udział } \\
\text { odpowiedzi }\end{array}$ \\
\hline 1. & $\begin{array}{c}\text { Mikrobiogazowanie - } \\
\text { zapewniające oszczędność na rachunkach za energię elektryczną }\end{array}$ & $6,48 \%$ \\
\hline 2. & $\begin{array}{c}\text { Małe elektrownie wiatrowe - } \\
\text { zapewniające oszczędność na rachunkach za energię elektryczną }\end{array}$ & $18,21 \%$ \\
\hline 3. & Panele fotowoltaiczne (PV) - & $28,09 \%$ \\
\hline 4. & zapewniające oszczędność na rachunkach za energię elektryczną & $3,40 \%$ \\
\hline 5. & Kompotły na biomasę - & $11,42 \%$ \\
\hline 6. & zapewniające oszczędność na rachunkach za ciepło - zapewniające oszczędność na rachunkach za ciepło & $29,01 \%$ \\
\hline 7. & Kolektory słoneczne - & $1,54 \%$ \\
\hline 8. & Żadne & $1,85 \%$ \\
\hline
\end{tabular}

Źródło: Opracowanie własne na podstawie badań ankietowych przeprowadzonych w MŚP województwa lubelskiego w latach 2014-2015

Po uzyskaniu odpowiedzi na pytanie - Jakiej wartości przedsięwzięcia planuje Pan/Pani w swoim przedsiębiorstwie? - okazało się, że ponad $54 \%$ podmiotów planuje przedsięwzięcia na poziomie do 100 tys. zł (Tabela 11). 
Tabela 11. Jakiej wartości przedsięwzięcia planowane są w przedsiębiorstwie w zakresie OZE?

\begin{tabular}{|c|c|c|}
\hline Lp. & Wyszczególnienie & Udział odpowiedzi \\
\hline 1. & Do 100 tys. zł & $54,55 \%$ \\
\hline 2. & $101-300$ tys. zł & $23,64 \%$ \\
\hline 3. & $301-500$ tys. zł & $9,09 \%$ \\
\hline 4. & Powyżej 500 tys. zł & $7,27 \%$ \\
\hline 5. & Powyżej 1 mln zł & $5,45 \%$ \\
\hline
\end{tabular}

Źródło: Opracowanie własne na podstawie badań ankietowych przeprowadzonych w MŚP województwa lubelskiego w latach 2014-2015

Nie ulega wątpliwości fakt, że poziom planów inwestycyjnych uzależniony jest od źródeł ich finansowania. Jako główne źródło finansowania inwestycji najczęściej wskazywany był zysk zatrzymany - prawie 39\%, a następnie możliwość skorzystania z dotacji z funduszy inwestycyjnych - ponad 17\% (Tabela 12). Program „Prosument” ma za zadanie wpieranie rozwoju odnawialnych źródeł energii w Polsce poprzez dotacje na zakup i montaż mikroinstalacji odnawialnych źródeł energii. W ramach programu można zainstalować urządzenia służące do produkcji zarówno energii elektrycznej, jak i cieplnej. Z programu mogą skorzystać osoby fizyczne, a także wspólnoty i spółdzielnie mieszkaniowe. W ramach całego programu, który ma działać do roku 2022, ma zostać rozdysponowanych łącznie 800 mln zł z możliwością zawierania umów do roku 2020 (http://www.programprosument.pl/o-programie-prosument).

Tabela 12. Jakie jest potencjalne źródło finansowania inwestycji w OZE?

\begin{tabular}{|c|c|c|}
\hline Lp. & Wyszczególnienie & Udział odpowiedzi \\
\hline 1. & Zysk zatrzymany & $38,76 \%$ \\
\hline 2. & Dopłaty właścicieli & $12,36 \%$ \\
\hline 3. & Kapitał nowego inwestora strategicznego & $1,12 \%$ \\
\hline 4. & Kredyt długoterminowy & $16,29 \%$ \\
\hline 5. & Kredyt preferencyjny & $2,81 \%$ \\
\hline 6. & Leasing finansowy & $6,18 \%$ \\
\hline 7. & Leasing operacyjny & $3,37 \%$ \\
\hline 8. & Dotacje z funduszy Unii Europejskiej & $17,42 \%$ \\
\hline 9. & Inne (jakie?) & $1,69 \%$ \\
\hline
\end{tabular}

Źródło: Opracowanie własne na podstawie badań ankietowych przeprowadzonych w MŚP województwa lubelskiego w latach 2014-2015

Dopiero na trzeciej pozycji pojawił się kredyt długoterminowy. W przebadanej grupie podmiotów występuje bardzo duże zróżnicowanie źródeł finansowania przedsięwzięć inwestycyjnych, o czym świadczy współczynnik zmienności na poziomie 1,092 . 


\section{Podsumowanie}

Rozwój przedsiębiorstw związany jest z inwestycjami. Inwestowanie jest procesem długotrwałym, w którym przedsiębiorstwo wydatkuje środki pieniężne w celu osiągnięcia określonych efektów ekonomicznych w przyszłości. Jak wykazano $\mathrm{w}$ dokonanym przeglądzie literatury, ostatnie lata przyniosły znaczny wzrost liczby inwestycji w odnawialne źródła energii. Konieczność sprostania wymogom Unii Europejskiej w dziedzinie poszanowania energii, a tym samym dążenie do pełni koncepcji zrównoważonego rozwoju, wiązać się będzie z jeszcze bardziej dynamicznym wzrostem udziału energii pochodzącej z OZE w zużyciu energii ogółem.

W oparciu o dostępną literaturę i przeprowadzone badania empiryczne dokonano analizy uwarunkowań inwestycji w zakresie odnawialnych źródeł energii w świetle wymagań zrównoważonego rozwoju. Przeprowadzone badania ankietowe dotyczyły ogółu zagadnień działalności inwestycyjnej MŚP w województwie lubelskim, ze szczególnym uwzględnieniem inwestycji w OZE.

Podsumowując rozważania na temat uwarunkowań inwestycyjnych w zakresie OZE przedsiębiorstw funkcjonujących na obszarze Lubelszczyzny, można stwierdzić, że głównym źródłem finansowania działalności inwestycyjnej mikro i małych firm pozostaje zysk zatrzymany. Środki własne były źródłem finansowania większości inwestycji, z kredytu bankowego skorzystało $16 \%$ firm. Jednak nadal pośród przedsiębiorców województwa lubelskiego występuje małe zainteresowanie wsparciem unijnym dla firm (17\%). Istnieje szeroki wachlarz instrumentów wspierających inwestycje w zakresie odnawialnych źródeł energii, jednak nie każdy przedsiębiorca jest tego świadomy. Jako powód niekorzystania ze wsparcia unijnego wskazują małą szansę na uzyskanie dotacji czy skomplikowane procedury przy ubieganiu się o dotację. Przeważająca część wydatków inwestycyjnych w analizowanych podmiotach nie przekraczała kwoty 100 tys. zł.

Przyjęto hipotezę badawczą o umiarkowanym poziomie działań inwestycyjnych firm z sektora małych i średnich przedsiębiorstw w województwie lubelskim. Mimo stopniowego przyrostu liczby inwestycji w odnawialne źródła energii nadal przedsiębiorcy inwestują jedynie w ograniczonym zakresie. W wyniku analizy planów inwestycyjnych badanej grupy przedsiębiorstw okazało się, że prawie $65 \%$ ankietowanych chciałoby zainwestować w odnawialne źródło energii. Jednak pośród nich zaledwie $22 \%$ podmiotów gotowych jest podjąć takie wyzwanie jak najszybciej i oczekuje, że średni okres zwrotu poniesionych kosztów z tytułu realizacji tej inwestycji ukształtuje się na poziomie nie dłuższym niż 2 lata. Natomiast w $43 \%$ przedsiębiorcy wykazują swoją gotowość do podjęcia tego rodzaju działań inwestycyjnych, jednak odkładają je na później i trudno jest im określić szacunkowy czas oczekiwania na zwrot poniesionych nakładów. 


\section{Literatura}

1. Bachorz W., Źródła finansowania inwestycji w zakresie odnawialnych źródeł energii. Dotacje i fundusze na rozwój eko-innowacji, http://www.rsi-wielkopolska.pl/files/59/32457e2a9f44-453f-8443-801ad9db7c9e.pdf (dostęp: 12.04.2016).

2. Bloomberg New Energy Finance (2013), Global Total New Investment in Clean Energy [za:] Szczepaniak K., Wojewnik-Filipkowska A. (red.) (2014), Inwestycje i nieruchomości w warunkach zrównoważonego rozwoju. Wybrane problemy, Uniwersytet Gdański, Sopot.

3. Ćwil M., Jak zrealizować inwestycje w OZE, http://www.zielona-energia.cire.pl/st,6, 284,tr,52,0,0,0,0,0,jak zrealizowac-inwestycje-w-oze.html (dostęp: 11.04.2016)

4. Dubel K. (1998), Uwarunkowania przyrodnicze w planowaniu przestrzennym, Ekonomia i Środowisko, Białystok.

5. Gnatowska R., Wąs A. (2015), Analiza opłacalności inwestycji w produkcję energii ze źródeł odnawialnych na przykładzie farmy wiatrowej przy założeniu wsparcia rządu dla „zielonej energii”, „Inżynieria i Ochrona Środowiska”, t. 18, nr 1.

6. Haugen G. (2014), Program Management, CRC Press, New York, [za:] Pabian A. (2015), Zrównoważone zarządzanie zasobami ludzkimi - zarys problematyki, „Zeszyty Naukowe Politechniki Częstochowskiej. Zarządzanie” nr 17, Sekcja Wydawnictw Wydziału Zarządzania Politechniki Częstochowskiej, Częstochowa.

7. http://imik.wip.pw.edu.pl/innowacje25/strona12.htm (dostęp: 01.12.2015).

8. http://strateg.stat.gov.pl (dostęp: 10.04.2016).

9. http://www.program-prosument.pl/o-programie-prosument (dostęp: 01.12.2015).

10. Krawczyk-Sokołowska I. (red.) (2012), Perspektywy zrównoważonego rozwoju przedsiębiorstw, Sekcja Wydawnictw Wydziału Zarządzania Politechniki Częstochowskiej, Częstochowa.

11. Kucęba R., Koszarek-Cyra A. (2015), Kierunki, bariery, determinanty zarządzania energią w organizacjach MŚP, „Zeszyty Naukowe Politechniki Śląskiej. Organizacja i Zarządzanie”, z. 83.

12. Mazur-Wierzbicka E. (2011), Zrównoważony rozwój energetyki odnawialnej w Polsce, http://www.ue.katowice.pl/fileadmin/_migrated/content_uploads/20_E.MazurWierzbicka_ Zrownowazony_rozwoj....pdf (dostęp: 12.04.2016).

13. Pabian A. (2015), Zrównoważone zarządzanie zasobami ludzkimi - zarys problematyki, „Zeszyty Naukowe Politechniki Częstochowskiej. Zarządzanie” nr 17, Sekcja Wydawnictw Wydziału Zarządzania Politechniki Częstochowskiej, Częstochowa.

14. Piechota K. (2014), Inwestycje w odnawialne źródła energii a polityka zrównoważonego rozwoju, [w:] Szczepaniak K., Wojewnik-Filipkowska A. (red.), Inwestycje i nieruchomości w warunkach zrównoważonego rozwoju. Wybrane problemy, Wydział Zarządzania Uniwersytetu Gdańskiego, Sopot.

15. Rechul H. (2004), Jaka jest różnica między ideą a zasadą zrównoważonego rozwoju?, „Wokół Energetyki" - sierpień 2004, http://www.cire.pl/pliki/2/jakaroznic.pdf (dostęp: 20.02.2016).

16. Rechul H. (2003), Wdrażanie energetyki odnawialnej a rozwój prywatnych elektrowni wodnych i wiatrowych, „Rynek Energii”, nr 1.

17. Sowiński J. (2014), Koszty energii elektrycznej z odnawialnych źródeł energii, „Przegląd Elektrotechniczny", nr 8.

18. Suska-Szczerbicka M. (2011), Wykorzystanie odnawialnych źródeł energii w strategii zrównoważonego rozwoju, VII Konferencja Samorządowa Dylematy rozwoju zrównoważonego, Kalisz, Uniwersytet Szczeciński, Wydział Nauk Ekonomicznych i Zarządzania, http://www.am-wind.com.pl/pl/publikacje (dostęp: 01.12.2015).

19. Zabłocki M. (2013), Determinanty wykorzystania odnawialnych źródeł energii w Polsce, „Technika Poszukiwań Geologicznych. Geotermia, Zrównoważony Rozwój”, nr 2. 


\title{
INVESTMENTS IN THE FIELD OF RENEWABLE ENERGY SOURCES IN THE LIGHT OF THE REQUIREMENTS OF SUSTAINABLE DEVELOPMENT ON THE EXAMPLE OF THE PROVINCE OF LUBLIN
}

\begin{abstract}
The basic condition that the market position of the company is not only the efficiency of the current management, but also the ability to make optimal investment decisions and sources of their financing. Investments in renewable energy are widely financed by banks and institutions that offer preferential loans for projects related to environmental protection, in installations related to renewable energy. Only $11 \%$ the total acquisition of energy comes from renewable sources, which may indicate that the process is at an early stage, but with a huge potential for rapid development. The article presents the sources of financing of small and medium-sized enterprises in the field of renewable energy sources. Investment analysis of the SME sector has been carried out on the basis of statistical information and surveys in the region of Lublin province. In a study of investment activities of enterprises in the Lublin importance attributed to investments in renewable energy sources and the issue of investment.
\end{abstract}

Keywords: investments, renewable energy, sources of financing, sustainable development 